\title{
Characterization and Desulfurization Possibilities of High Sulfur Gediz-Turkey Coal
}

\author{
Uğur Demir \\ Department of Mining Engineering, Dumlupınar University, Kütahya 43100, Turkey
}

\begin{abstract}
Coal is one of the important energy sources, but it causes serious environmental problems such as air pollution, acid rain and greenhouse effects. Sulfur in coal is one of the responsibilities of these negative effects. Coal includes two types of sulfur: organic and inorganic. While inorganic sulfur can be completely removed with physical desulfurization methods, organic sulfur can be removed only by chemical desulfurization methods. But chemical methods are not only expensive but also difficult processes. Firstly in desulfurization, types of the sulfur content in coal should be well characterized. High sulfur Gediz-Turkey coal has been chosen to this study. This coal basin is located in the centre of the Turkey. In this study, characterization and desulfurization possibilities of high sulfur Gediz coal were investigated. For this purpose, several physical and chemical characterization methods such as proximate and ultimate coal analysis (ash, calorific value, volatile matter, moisture and sulfur analysis), mineralogical and petrographic analysis, fourier transform infrared spectroscopy, scanning electron microscope were used. Results of these analysis are shown that Gediz coals include 3.15\% pyritic sulfur and 2.89\% organic sulfur. Removing pyritic sulfur from Gediz-Turkey coal with physical methods such as gravity and sink-float separation is not possible because pyrite particle has 1-2 micron liberation size in coal.
\end{abstract}

Key words: Characterization, desulfurization, high sulfur, Gediz coal.

\section{Introduction}

Coal is one of the most important sources of energy. Its use around the world will continue to expand during the next several decades. Unfortunately, the use of coal causes several kinds of environmental and health hazard problems. The control of pollutants such as $\mathrm{SO}_{2}, \mathrm{NO}_{2}$ and particle matter after burning such low quality coals will require low cost new technologies. Combustion of high sulfur coal produces $\mathrm{SO}_{2}$ which is toxic and corrosive. Sulfur dioxide is subsequently converted to $\mathrm{SO}_{3}$, which in contact with water forms sulfuric acid. In weathered coal, acidic mine water percolates into the round and makes the groundwater highly acidic. $\mathrm{SO}_{3}$ leads to formation of acid rain, and corrosion of boilers, underground pipelines, metallic installations, mine machinery etc. $[1,2]$.

Until recently, Turkish economy has been growing

Corresponding author: Ugur Demir, Ph.D., assistant professor, main research field: desulfurization of solid fuels. rapidly, and demand for electrical energy has increased approximately $8 \%$ per year on average. Total installed electric capacity of Turkey reached $71,800 \mathrm{MW}$ by end of 2015 [3]. Over half of this capacity is thermal energy which is derived from coal and natural gas, and remaining capacity comes from other sources [4]. Coal is clearly important to the Turkish economy. Turkish lignite reserves have been estimated to be over 13 billion metric tons. These low quality lignitic coals are characterized by high moisture, ash, volatile matter and sulfur contents. Almost $75 \%$ of the total reserves have a calorific value below $2,500 \mathrm{kcal} / \mathrm{kg}$, while only $8 \%$ is between $3,000-5,000 \mathrm{kcal} / \mathrm{kg}[5,6]$.

Sulfur in coal is present both inorganically and organically. The inorganic sulfur in coal consists predominantly of sulfides (pyrite, sphalerite, galena, arsenopyrite and others) and sulfates (barite, gypsum, anhydrite and a number of iron sulfates) [2, 7-10]. The pyrite is generally the predominant inorganic sulfur in coal. Particles of pyrite randomly distributed as 
crystals throughout the coal, but are not bound to it. The organic sulfur in coal is covalently bound into its large complex structure and is difficult to remove physically or chemically, in contrast to pyritic or inorganic sulfur [11, 12]. Organic sulfur in coal occurs in both aliphatic and aromatic networks. These include thiol, sulphide, disulphide, thioether, thioketonic and thiophene. Thiophene is resistant to oxidation when high sulfur coals are heated at $180{ }^{\circ} \mathrm{C}$. Thiophene even reacts slowly with water at $300{ }^{\circ} \mathrm{C}$, the reaction proceeds readily at $240{ }^{\circ} \mathrm{C}$ at $\mathrm{pH}$ 1 [13].

Combustion of high sulfur and ash coal leads to serious environmental pollution and other hazardous effects. Therefore, removal of the sulfur from a coal prior to its utilization has attracted interest of all concerned. To determine the suitability of any particular coal desulfurization method, knowledge of the distribution of different forms of sulfur within the coal is required [14]. Desulfurization of coal may be achieved by physical, chemical and biological methods. The physical methods are based on the differences in the physical properties of the sulfur and the carbonaceous part of the coal. In the physical processes coal is crushed, ground and washed. This allows for up to $90 \%$ of pyrite to be removed. However, depending on the type of coal, a considerable amount of finely distributed pyrite as well as organic sulfur can remain in and attach to the coal particles. The inability of physical methods to completely remove even the inorganic sulfur has led to the development of many chemical desulfurization processes. Desulfurization by chemical means involves solubilization of the inorganic constituents or their converted forms in various solvents [2]. These include carbonization in different atmospheres, air oxidation, wet oxidation, Mayer process, chlorination and extraction with sodium hydroxide, copper chloride and ethanol solutions [12, 15, 16]. The biological methods are performed under mild conditions with no harmful reaction products and the value of coal is not affected. Several microorganisms such as Thiobacillus ferrooxidans and Thiobacillus tiooxidansare are used in these processes [12].

In this study, characterization and desulfurization possibilities of high sulfur Gediz-Turkey coal samples were investigated. For this purpose, physical and chemical analysis methods were used.

\section{Characterization and Desulfurization Possibilities}

Coal used in this study was provided from Kütahya-Gediz, Turkey. The coalfield is located to Gediz in the middle of the Western of Turkey (Fig. 1). This coalfield has 15 million tons reserves. Two coal seams, the upper and the lower are located at the base of the Gediz formation. They are separated by about 3 $m$ thick black claystone and brown to dark brown clayey dolomitic limestone in the center of the coalfield. The average thickness of the upper seam is $1.7 \mathrm{~m}$ and lower seam $1.2 \mathrm{~m}$ [17].

\subsection{Characterization}

\subsubsection{Proximate and Ultimate Analysis}

Coal samples air-dried were crushed and milled to less than $0.25 \mathrm{~mm}$ particle size by laboratory type crusher and grinder before characterization studies. Proximate, elemental and sulfur forms of Gediz coal sample analyses were given in Table 1. The ash, sulfur and its forms in the samples were determined by ASTM D 3173, ASTM D 3177 and ASTM D 2492 respectively. IKA c7000 calorimeter was used to determine the calorific value of sample.

As seen from Table 1, Gediz coal includes very high total sulfur $(7.06 \%)$ and organic sulfur constitutes an important part of total sulfur. The forms of sulfur in coal are pyritic sulfur (3.55\%), organic sulfur $(2.98 \%)$ and sulfate sulfur $(0.62 \%)$. Pyritic and organic sulfur generally account for the bulk of sulfur in coal. There are two forms of pyrites: 1-diagenetic framboidal pyrite which is distributed in the organic matrix; 2-epigenetic crystals and massive grains 
Table 1 Proximate, elemental analysis and sulfur forms of Gediz coal.

\begin{tabular}{llll}
\hline Proximate & $\%$ & Ultimate & $\%$ \\
\hline Moisture & 3.3 & Carbon & 78.41 \\
Ash & 25.99 & Hydrogen & 5.12 \\
Volatile matter & 32.81 & Nitrogen & 1.61 \\
Fixed carbon & 37.9 & Oxygen (dif.) & 7.8 \\
& & Total Sulfur & 7.06 \\
Calorific value & $5,607(\mathrm{kcal} / \mathrm{kg})$ & Organic Sulfur & 2.89 \\
& & Pyritic Sulfur & 3.55 \\
& & Sulfatic Sulfur & 0.62 \\
\hline
\end{tabular}

Table 2 Chemical analysis of Gediz coal.

\begin{tabular}{|c|c|c|c|c|c|c|c|c|}
\hline & $\mathrm{SiO}_{2}$ & $\mathrm{Al}_{2} \mathrm{O}_{3}$ & $\mathrm{Fe}_{2} \mathrm{O}_{3}$ & $\mathrm{CaO}$ & $\mathrm{MgO}$ & $\mathrm{Na}_{2} \mathrm{O}$ & $\mathrm{K}_{2} \mathrm{O}$ & $\mathrm{SO}_{3}$ \\
\hline$\%$ & 4.15 & 0.014 & 3.75 & 0.25 & 0.16 & 2.26 & 0.14 & 22.07 \\
\hline
\end{tabular}

occurring mainly infills within microfractures of the organic matrix. Liberation size of pyritic sulfur in Gediz coal was determined as 1-5 micrometer.

\subsubsection{Chemical Analysis}

The chemical composition of Gediz coal was given in Table 2. Spectro X-Lab 2000 XRF device was used in this analysis. As seen in Table 2, important part of coal mineral matters are silicates and ferrous minerals.

\subsubsection{Mineralogical and Petrographic Analysis}

Mineralogical analysis of Gediz coal was given in Fig. 2 and made with XRD device (RigakuMiniFlex). XRD analysis was applied to raw coal sample to identify key mineral matter compounds. Fig. 2 shows that the major mineral phases are pyrite, melnicovite, quartz and calcite. However, trace of other minerals like kaolinite, illite, dolomite, gypsum and marcasite, and mixed clays minerals, feldspar and opal are also observed in coal. Petrographic analysis of the Gediz coal samples are in general composition by higher amounts of macerals of the vitrinite group (87\%) than exinite (2\%) and inertinite group (2\%).

2.1.4 Fourier FTIR (Transform Infrared Spectroscopy) Analysis

FTIR spectra of coal sample in the range of $4,000-400 \mathrm{~cm}^{-1}$ was run in a Perkin Elmer BX FTIR device on $\mathrm{KBr}$ pellets (Fig. 3). To permit measurements in the aromatic $\mathrm{C}-\mathrm{H}$ out of plane zone (900-700 $\mathrm{cm}^{-1}$ ). Spectra were recorded by co-adding 124 scans at a resolution of $2 \mathrm{~cm}^{-1}$. Software facilities were used for baseline corrections of spectra, which were scaled to $1 \mathrm{mg}$ sample $\mathrm{cm}^{-2}$. The aromatic (Har) and aliphatic (Hal) hydrogen distribution in the solid samples was calculated from the integrated absorbance of the bands at 900-700 and 3,000-2,800 $\mathrm{cm}^{-1}$, respectively. The extinction coefficients used for converting integrated absorbance areas to concentration units were 541 and 710 abs $\mathrm{cm}^{-1}$ $\mathrm{mg} \cdot \mathrm{cm}^{-2}$ for aromatic and aliphatic bands, respectively, for the lignite and subbituminous coal. As shown in Fig. 3, the mineral matter peaks is observed in the 536, 667, 694 and 1,099 $\mathrm{cm}^{-1}$ wavelength. At 914, 1,033, 3,620 and 3,694 $\mathrm{cm}^{-1}$ wavelength shows the kaolin conclusion. Quartz, pyrite and jibs are seen in 779, 1,164 and $470 \mathrm{~cm}^{-1}$ wavelength, respectively. Carboxyl $\mathrm{C}=\mathrm{O}$ groups at $1,700 \mathrm{~cm}^{-1}, \mathrm{O}-\mathrm{H}$ strongly bonds at 3,300-3,400 $\mathrm{cm}^{-1}$ wavelengths are seen.

Strong aliphatic $\mathrm{C}-\mathrm{H}$ bonds were observed intensively at 2,850 $\mathrm{cm}^{-1}$. At 1,033-1,100 $\mathrm{cm}^{-1}$ wavelength Cal-O-Cal and Car-O-Cal bonds are observed in association with the minerals.

\subsubsection{SEM (Scanning Electron Microscopy)} Analysis

The optical microscopy investigations shows that pyrite is present in the form of discrete grains, fracture and cavity filling, regular and irregular framboidal with particle size ranging from 1-5 micrometer. SEM (Scanning Electron Microscopy) studies show that pyrite is distributed even finer than 2 micrometer. Fine 


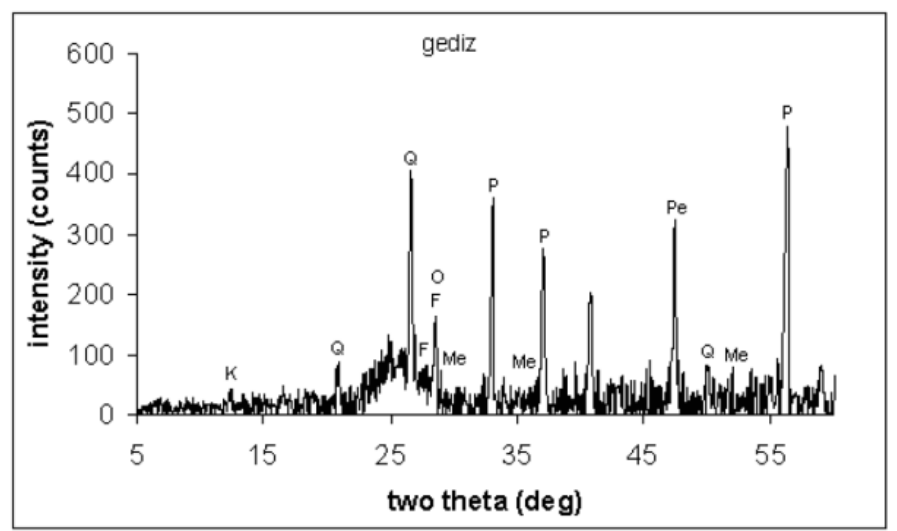

Fig. 2 XRD pattern of Gediz coal (K, Kaoline; Q, Quartz; P, Pyrite; Me, Melnicovite; F, Feldispar).

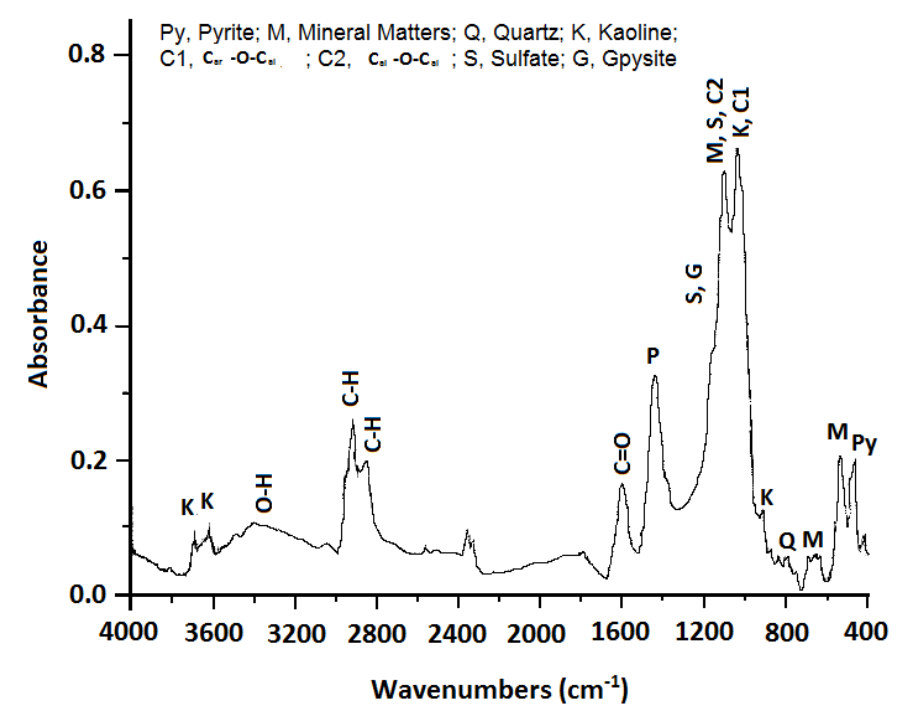

Fig. 3 FTIR analysis of Gedizcoal.

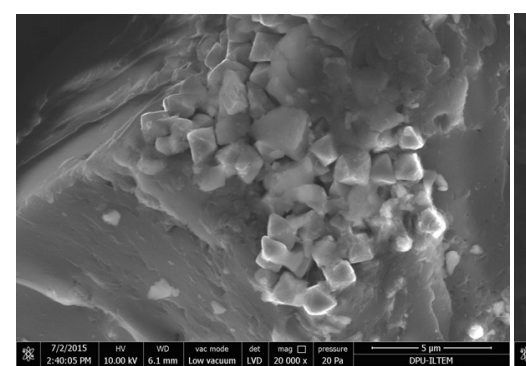

Fig. 4 SEM images of Gediz-Turkey coal (mag. 20,000×).

grinding is needed for the removal of this finely distributed sulfur from coal, and it is impossible using the conventional methods in practice.

\subsection{Desulfurization Possibilities}

The processes of sulfur removal from coal prior to combustion can be subdivided into physical and

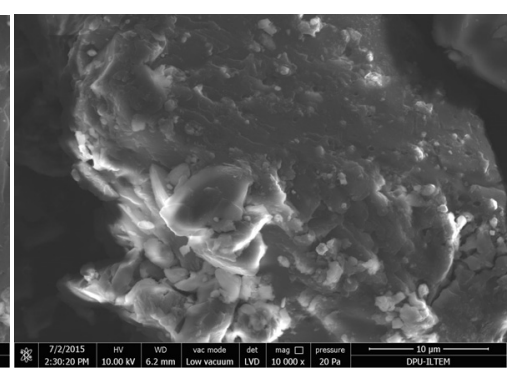

chemical methods. Of these, physical methods can remove soluble sulfates and a considerable portion of the coarse pyrite, but the fine pyrite and organic sulfur remain largely untouched [18, 19]. A number of chemical methods are under development with the intent to remove all of the pyrite and at least a portion of the organic sulfur. In general, there are three 
chemical coal desulfurization strategies: 1-oxidation of sulfur in the coal to form soluble sulfates; 2-conversion of the sulfur to elemental sulfur in which it can be vaporized or removes by organic solvents; 3-reaction with hydrogen to form gaseous hydrogen sulfide [18].

In this section, inorganic and organic sulfur removal facilities in Gediz coal will be examined. Properties of inorganic and organic sulfur content of the coal will be studied and researched for suitable sulfur removal methods.

\subsubsection{Physical Desulfurization}

Basically, physical desulfurization can be divided into four broad categories based on the physical properties that are used to affect a separation: specific gravity, surface properties, magnetic susceptibility and electrical conductivity. Gravity separation depends on the specific gravity difference between coal and sulfurs. The specific gravity of clean coal is usually between 1.3 and $1.7 \mathrm{~g} / \mathrm{cm}^{3}$ whereas the specific gravity of mineral matter is between 2.5 and $5.0 \mathrm{~g} / \mathrm{cm}^{3}$ $[20,21]$. Gravity separation processes are relatively simple and include the most conventional coal cleaning methods such as jigging, shaking tables, heavy medium, hydrocyclone and air classification. Several sulfur removing methods including froth flotation, oil agglomeration and solvent partitioning make use of the difference in surface properties to separate both sulfur and ash-forming mineral matter from coal. In one commonly used process (dense medium cyclone) the coal particles sink or float in a medium of controlled density according to their densities. The heavier the coal particles contain a large amount of minerals (including pyrites), the float product results are purer than the original coal [20]. Generally, the coal minerals except pyrite tend to be quite hydrophilic (water attracting), whereas the coal macerals are either hydrophobic (water repelling) or at least less hydrophilic than the minerals. In the froth flotation process, the hydrophobic coal particles cling to air bubbles and rise to the top of a liquid suspension where the clean coal is recovered in froth. A frothing reactive is normally added to facilitate the flotation of the coal. The hydrophilic minerals are left behind in the aqueous suspension. In oil agglomeration a small amount of fuel oil is added to agitated slurry of coal and water, causing the hydrophobic coal particles to become oil-coated and agglomerated into larger clumps of coal and oil. The large agglomerates can be separated from the unagglomerated mineral particles by screening the suspension [21]. Magnetic separation relies on the difference in magnetic susceptibility of coal and mineral matter, either in air or aqueous slurries. Electrical methods employ electrical charges and magnetic forces to effect separation. Electrostatic separation depends on the difference in electrical change of various particles produced by one of several mechanisms in air [20,21].

The chemical composition, physical size and mode of distribution of the ash-forming mineral matter and sulfur types in coal greatly affect the way in which it can be removed from coal. Certain physical cleaning methods are well-developed, inexpensive and trouble-free when applied to the separation of large discrete mineral particle from coal. However, finely disseminated pyrite and mineral particles cannot be removed efficiently and economically by physical methods. Also, physical methods do not remove the impurities which are bonded chemically to the organic matrix of the coal.

It is shown that in characterization studies of Gediz-Turkey coal, coal samples included high sulfur which is $3.55 \%$ pyritic, $2.89 \%$ organic and $0.62 \%$ sulfatic sulfur. Sulfur content of Gediz coal is high both in inorganic sulfur and organic sulfur. Pyritic sulfur liberation particle size is very fine (1-2 micron) and disseminated in coal matrix. It is also concluded from this study that entire removal of inorganic sulfur from Gediz coal is not possible by physical desulfurization methods.

\subsubsection{Chemical Desulfurization}

The organic sulfur form is about $50 \%$ of the total 
sulfur that cannot be removed by physical methods. Removal of organic sulfur requires chemical desulfurization techniques that can remove inorganic sulfur and ash-forming minerals, too. Although chemical desulfurization of coal is not profitable in the current economic conditions, it may become economical in the future, as $\mathrm{SO}_{2}$ emission regulations are tightened and low sulfur coal reserves are depleted $[22,23]$. A number of chemical processes are under development which varies substantially in their approach. Basically, these processes can be classified into four general types: oxidative, reductive, caustic and miscellaneous treatments [21].

Several oxidizing chemical/agents as air, oxygen, chlorine, nitrogen oxide and ferric salts are sufficiently strong (at elevated temperatures) to convert the pyritic and part of the organic sulfur in coal to water soluble sulfate. Oxyde sulfurization processes employ oxygen or air in an aqueous solution at an elevated temperature and pressure. Caustic treatments; it has long been known that caustic, either in the form of a hot melt or a hot aqueous solution, is an effective chemical for removing sulfur and ash-forming mineral matter from coal [21].

The chemical desulfurization methods are based on solubilization of the sulfur in different chemicals. Well known desulfurization processes include caustic treatment $(\mathrm{NaOH}, \mathrm{KOH}, \mathrm{CaOH}$ vs), acidic treatment ( $\mathrm{HCl}, \mathrm{HNO}_{3}, \mathrm{H}_{2} \mathrm{SO}_{4}, \mathrm{HF}, \mathrm{H}_{2} \mathrm{O}_{2}$ vs) and thermal treatment [1, 18, 22, 24-28]. Thermal treatment can be used efficiently for desulfurization of coals by both removal of organic sulfur species and pyrite decomposition prior to combustion. In this process, while the raw coal is desulfurized, some useful gaseous and liquid produce and residual char are also obtained. Thermal treatment combined with char combustion appears to be the most efficient technology for the utilization of high sulfur coals [29, 30]. The extent of sulfur removal from coal by thermal treatment depends on many factors, such as temperature, nature of the atmosphere and residence time, as well as coal type [31]. Pyrite decomposes to pyrrhotite, $\mathrm{H}_{2} \mathrm{~S}$ and some pyrrhotite reduction to iron is observed during thermal treatment. Pyrite begins to decompose to $\mathrm{FeSx}$ around $350{ }^{\circ} \mathrm{C}$, this reaction is finished at $750-950{ }^{\circ} \mathrm{C}[30,32]$.

An important part of inorganic sulfur forms in Gediz-Turkey coal is pyritic sulfur, therefore removal of pyritic sulfur from coal can be achieved by acidic or alkaline chemical. During this chemical treatment while pyritic sulfur is converted to soluble forms between organic sulfur and coal matrix, weak bonds (C-S, S-S, H-S) are broken or strong bonds are weaked. As it can be seen, all of the characterization studies for both fine pyritic sulfur and organic sulfur can be removed only in chemical desulfurization methods.

\section{Conclusion}

The Gediz coalfield in the western part of Turkey mainly contains high sulfur $(7.06 \% \mathrm{~S})$ subbituminous coal old Middle Miocene age. The coalfield is in general characterized by higher amounts of macerals of the vitrinite group than liptinite and inertinite contents. Minerals identified by XRD in the coal include major quartz, pyrite and calcite with subsidiary amounts of kaolinite, illite, dolomite, gypsum, marcasite, rarely mixed layer clay minerals, feldspar and opal. Ash contents are relatively high, and detrital minerals are an important component in the coal samples. As inorganic sulfur pyrite and marcasite were detected by SEM, these iron sulfides within microfractures and micropores and syngenetic framboidal pyrites dispersed in the coal matrix.

This study concludes that as investigated for all identified properties of Gediz-Turkey coal, removal of sulfur types from coal by physical desulfurization methods are not possible. Nowadays, applications of chemical desulfurization methods are difficult in current economical conditions. Therefore, Gediz-Turkey coal must not be used as a fuel but alternative usage areas should be investigated. 


\section{References}

[1] Liu, G., Zheng, L., Gao, L., Zhang, H., and Peng, Z. 2005. "The Characterization of Coal Quality the Jining Coalfield." Energy 30 (10): 1903-14.

[2] Mukherjee, S., Mahjuddin, S., and Borthakur, P. C. 2001. "Demineralization and Desulfurization of Subbituminous Coal with Hydrogen Peroxide.” Energy \& Fuels 15 (6): 1418-24.

[3] The Electricity Generation Company of Turkey Website. 2016. Accessed June 29, 2016. www.euas.gov.tr 2016.

[4] Palmer, S. R., Hippo, E. J., and Dorai, X. A. 1994. "Chemical Coal Cleaning Using Selective Oxidation." Fuel 73 (2): 161-70.

[5] Ateşok, G., Perek, K. T., Dinçer, H., and Çelik, M. S. 1999. "Reduction of Ash and Sulfur Contents of Low-Rank Turkish Semicoked Lignite by High Intesity Dry Magnetic Separation." Coal Preparation 20 (3-4): 179-90.

[6] TKİ. 2014. Coal Sector Report (lignite). Republic of Turkey Ministry of Energy and Natural Sources.

[7] Chalkins, W. H. 1994. "The Chemical Forms of Sulfur in Coal: A Review." Fuel 73 (4): 475-84.

[8] Jorjani, E., Rezai, B., Vossoughi, M., Osanloo, M., and Abdollahi, M. 2004. "Oxidation Pretreatment for Enhancing Desulfurization of Coal with Sodium Butoxide.” Minerals Engineering 17 (4): 545-52.

[9] Pietrizak, R., and Wachowska, H. 2006. "The Influence of Oxidation with $\mathrm{HNO}_{3}$ on the Surface Composition of High-Sulphurcoald: XPS Study." Fuel Processing Technology 87 (11): 1021-9.

[10] Uzun, D., and Özdoğan, S. 2006. "Sulfur Removal from Original and Acid Treated Lignites by Pyrolysis." Fuel 85 (3): 315-22.

[11] Constanti, M., Giralt, J., and Bordons, A. 1994. "Desulphurization of Dibenzothiophene by Bacteria." World Journal of Microbiology \& Biotechnology 10 (5): 510-6.

[12] Prayuenyong, P. 2002 "Coal Biodesulfurization Processes.” Songklanakarin J. Sci. Technology 24 (3): 493-507.

[13] Borah, D., Baruah, M. K., and Haque, I. 2001. "Oxidation of High Sulphur Coal. Part 1. Desulphurization and Evidance of the Formation of Oxidised Organic Sulphur Species." Fuel 80 (4): 501-7.

[14] Jorjani, E., Yperman, J., Carleer, R., and Rezai, B. 2006. "Reductive Pyrolysis Study of Sulfur Compounds in Different Tabas Coal Samples (Iran)." Fuel 85 (1): 114-20.

[15] Yaman, S., and Küçükbayrak, S. 1996. "Oxydesulfurization of a Turkish Hard Lignite with
Ammonia Solution.” Energy Sources 18 (6): 677-83.

[16] Klein, J. 1998, "Technological and Economical Aspects of Coal Biodesulfurization." Biodegradation 9 (3-4): 293-300.

[17] Karayiğit, A. I., Spears, D. A., and Booth, C. A. 2000. "Antimony and Arsenic Anomalies in the Coal Seams from the Goker Coalfield, Gediz, Turkey." International Journal of Coal Geology 44 (1): 1-17.

[18] Karaca, S., Akyürek, M., and Bayrakçeken, S. 2003. "The Removal of Pyritic Sulfur from Aşkale Lignite in Aqueous Suspention by Nitric Acid." Fuel Processing Technology 80 (1): 1-8.

[19] Mukherjee, S., and Borthakur, P. C. 2003. "Demineralization of Subbitumious High Sulphur Coal Using Mineral Acids.” Fuel Processing Technology 85 (2): 157-164.

[20] Trindade, S. C., and Kolm, H. H. 1973. "Magnetic Desulfurization of Coal." IEEE Transactions on Magnetics 9 (3): 310-3.

[21] Fan, C. W. 1984. "Coal Desulfurization and Demineralization by Chemical/Physical Treatments." Iowa State Universtiy, Ames, Iowa, USA.

[22] Jorjani, E., Rezai, B., Vossoughi, M., Osanloo, M., and Abdollahi, M. 2004. "Oxidation Pretreatment for Enhancing Desulfurization of Coal with Sodium Butoxide." Minerals Engineering 17 (4): 545-52.

[23] Kawatra, S. K., and Eisele, T. C. 2001. Coal Desulfurization, High-Efficiency Preparation Methods, Printed by Edwards Brothers, Ann Arbor, Taylor \& Francis Inc. 349.

[24] Alam, H. G., Moghaddam, A. Z., and Omidkhah, M. R. 2008. "The Influence of Process Parameters on Desulfuruzation of Mezinocaol by $\mathrm{HNO}_{3} / \mathrm{HclLeaching."}$ Fuel Processing Technology 90 (1) 1-7.

[25] Mukherjee, S., and Borthakur, P. C. 2003. "Effect of Leaching High Sulphur Subbituminous Coal by Potassium Hydroxide and Acid on Removal of Mineral Matter and Sulphur." Fuel 82 (7): 783-8.

[26] Mukherjee, S., and Borthakur, P. C. 2003. "Effect of Alkali Treatment on Ash and Sulphur Removal from AssmCoal." Fuel Processing Technology 85 (2): 93-101.

[27] Ceylan, K., Karaca, H., and Önal, Y. 1999. "Thermogravimetric Analysis of Pretreated Turkish Lignites." Fuel 78 (9): 1109-16.

[28] Karaca, H., and Ceylan, K. 1997. "Chemical Cleaning of Turkish Lignite by Leaching with Aqueous Hydrogen Peroxide." Fuel Processing Technology 50 (91): 19-33.

[29] Erşahin, H., Şara, O. N., and Boncukoğlu, R. 1997. "Desulphurizaitonof Two Turkish Lignite in an Entrained Flow Reactor." Journal of Analytical and Applied Pyrolysis 44 (1): 65-74. 
[30] Koca, H., Kockar, O. M., and Koca, S. 2007. "Desulphurizaiton of Lignites by Slow, Fast and Flash Pyrolysis and High Intensity Dry Magnetic Separation." Energy Sources Part A 29 (16): 1457-70.

[31] Xu, L., Yang, J., Li, Y., and Liu, Z. 2003. "Effect of
Organic Gaseous Additives on Desulfurization of Coal during Pyrolysis." Energy Sources Part A 25 (10): 1033-42.

[32] Uzun, D., and Özdoğan, S. 2006. "Sulfur Removal from Original and Acid Treated Lignites by Pyrolysis." Fuel 85 (3): 315-22. 